\title{
Quality of life in neuropathic pain: a literature review
}

\author{
Qualidade de vida em dor neuropática: uma revisão de literatura \\ Calidad de vida en el dolor neuropático: una revisión de la literature
}

\begin{abstract}
Introduction: Neuropathic pain may develop after injury to the central nervous system, peripheral or both, when deleterious changes occur along the nociceptive modulatory pathways of the central nervous system. Proper management requires an interdisciplinary approach, as it can impact quality of life. Objectives: This review of the literature aims to assess the impact of pharmacological and non-pharmacological factors in the quality of life of patients with chronic neuropathic pain. Methodology: A systematized virtual search was carried out in PubMedß, collected articles between January 2010 and May 2020 using the terms "neuropathic pain", "treatment", "human" and "systematic review" using the filters of "systematic reviews " $E$ " published in the last 10 years ". All articles were formed by two independent reviewers and tabulated in a spreadsheet using Microsoft Excel® software. Results: Nonpharmacological interventions were addressed by most articles. Some articles addressed pharmacological interventions, with painful diabetic peripheral neuropathy being the main etiology. The most used quality of life measurement tools were: Medical Outcomes Study 36 (SF-36); EuroQol-5 Dimension (EQ-5D) and Beck Depression Inventory Score (BDI). Conclusion: The scarcity of high-quality studies that measure quality of life through validated tools is an obstacle to credible analysis of the impact of interventions on the life of chronic pain patients, however, in a preliminary way, cognitive behavioral therapy and the use of Spray THC/CBD oromucous has the potential to have a beneficial impact on quality of life.
\end{abstract}

Keywords: Quality of life; Chronic pain; Therapeutic approaches.

\section{Resumo}

Introdução: A dor neuropática pode desenvolver-se após a lesão do sistema nervoso central, periférico ou ambos, quando ocorrem alterações deletérias ao longo das vias modulatórias nociceptivas do sistema nervoso central. O manejo adequado demanda uma abordagem interdisciplinar, pois pode impactar a qualidade de vida. Objetivos: Esta revisão da literatura tem por objetivo avaliar o impacto de intervenções farmacológicas e não-farmacológicas na qualidade de vida dos pacientes com dor neuropática crônica. Metodologia: Foi realizada uma busca virtual sistematizada no PubMed®, coletado os artigos entre Janeiro de 2010 e Maio de 2020 utilizando os termos "Neuropathic pain", "treatment", "human" e "systematic review" utilizando os filtros de "Systematic Reviews" e "Published in the last 10 years". Todos os artigos foram analisados por dois revisores independentes e tabulados em uma planilha utilizando o software Microsoft Excel@. Resultados: As intervenções não farmacológicas foram abordadas pela maioria dos artigos. Alguns artigos abordaram intervenções farmacológicas, sendo a neuropatia periférica diabética dolorosa a principal etiologia descrita. As ferramentas de mensuração da qualidade de vida mais utilizadas foram: Medical Outcomes Study 36 (SF-36); EuroQol-5 dimension (EQ-5D) e Beck Depression Inventory Score (BDI). Conclusão: A escassez de estudos de alta qualidade que mensuram a qualidade de vida através de ferramentas validadas é um empecilho para análise verossímil do impacto das intervenções na vida do paciente com dor crônica, entretanto de forma preliminar a terapia cognitiva comportamental e o uso de Spray Oromucoso de THC/CBD têm potencial de impacto benéfico na qualidade de vida.

Palavras-chave: Qualidade de vida; Dor crônica; Condutas terapêuticas. 


\begin{abstract}
Resumen
Introducción: El dolor neuropático puede desarrollarse después de una lesión del sistema nervioso central, periférico o ambos, cuando ocurren cambios deletéreos a lo largo de las vías moduladoras nociceptivas del sistema nervioso central. El manejo adecuado requiere un enfoque interdisciplinario, ya que puede afectar la calidad de vida. Objetivos: Esta revisión de la literatura tiene como objetivo evaluar el impacto de las intervenciones farmacológicas y no farmacológicas en la calidad de vida de los pacientes con dolor neuropático crónico. Metodología: Se realizó una búsqueda virtual sistematizada en PubMed®, se recopilaron artículos entre enero de 2010 y mayo de 2020 utilizando los términos "Dolor neuropático", "tratamiento", "humano" y "revisión sistemática" utilizando los filtros de "Revisiones sistemáticas" y "Publicado en los últimos 10 años". Todos los artículos fueron analizados por dos revisores independientes y tabulados en una hoja de cálculo utilizando el software Microsoft Excel®. Resultados: La mayoría de los artículos abordaron las intervenciones no farmacológicas. Algunos artículos abordan intervenciones farmacológicas, siendo la neuropatía periférica diabética dolorosa la principal etiología descrita. Las herramientas de medición de la calidad de vida más utilizadas fueron: Medical Outcomes Study 36 (SF-36); Dimensión EuroQol-5 (EQ-5D) y Beck Depression Inventory Score (BDI). Conclusión: La escasez de estudios de alta calidad que midan la calidad de vida a través de herramientas validadas es un obstáculo para un análisis creíble del impacto de las intervenciones en la vida de los pacientes con dolor crónico, sin embargo, de manera preliminar, la terapia cognitivoconductual y el uso de Spray THC / CBD omucousum tiene el potencial de tener un impacto beneficioso en la calidad de vida.
\end{abstract}

Palabras clave: Calidad de vida; Dolor crónico; Conductas terapéuticas.

\title{
1. Introduction
}

Since ancient times, the concept of pain has been the subject of debate. The term pain first appeared in oriental medicine in the medicine book Huang Di Nei Jing more than 3,000 years ago. It was believed that pain was a result of the disparity between 'yin' and 'yang', thus therapeutic approaches were directed towards establishing balance (Chen, 2011).

In Western medicine, the term was first mentioned in Homer's epics, the Iliad, and the Odyssey around the 8th century BC in ancient Greece (Chen, 2011). The term was traced back three centuries later (5 BC), when Hippocrates and his followers published 'The Hippocratic Collection' (Perl, 2007).

In another aspect, the relation of the brain as the seat of the sensation of pain was only described in the Renaissance period by Andreas Vesalius (1514-1564). The founder of modern human anatomy performed systematic autopsies and sought a relationship between the painful sensation and the organs studied. (Hadzic et al., 2014). After 1800, several theoretical frameworks were proposed to explain the physiological basis of pain. However, none fully explains all aspects of pain perception (Collier, 2018; Moayedi \& Davis, 2013).

Since its founding in 1973, the International Association for the Study of Pain (IASP), through its taxonomy committee, has continuously sought to identify, define and classify pain in its various forms (Miranda, Seda Jr \& Pelloso, 2016). The most recent definition of pain, accepted by the IASP in early 2020, defines pain as "An unpleasant sensory and emotional experience, associated, or similar to that associated, with an actual or potential tissue injury" (Raja et al., 2020).

Neuropathies are common clinical problems and for many patients with neuropathy pain is the main complaint (Ballantyne, 2018). Pain of neuropathic origin is caused by dysfunction or nerve damage and, more broadly, it is a consequence of a disease of the somatosensory system (Jensen et al., 2011).

The IASP in conjunction with the World Health Organization (WHO) created a task force to synthesize in a structured way a definition for chronic neuropathic pain, carried out through the International Classification of Diseases 11 (ICD-11). The syndrome is defined as "pain that can be spontaneous or provoked, such as an increased response to a painful stimulus (hyperalgesia) or a painful response to a normally non-painful stimulus (allodynia)" (Raja et al., 2020).

Diagnosis of chronic neuropathic pain requires a history of nervous system injury or disease and a matching neuroanatomic distribution. Positive and negative neurological symptoms and signs indicating the involvement of the somatosensory nervous system must be compatible with the territory of innervation of the affected nervous structure. These criteria apply to the diagnosis of all entities involving chronic neuropathic pain (Scholz et al., 2019). 
Neuropathic pain has major negative impacts on a patient's quality of life and is difficult to manage, commonly requiring a multidisciplinary approach and not limited to pharmacological treatment (Ballantyne, 2018).

Patients with neuropathic pain report substantially low levels of Health-Related Quality of Life (HRQoL) compared to the general population (Meyer-Rosberg et al., 2001). Individual patient analyzes indicate that those who achieve good pain relief achieve important benefits in other domains, significantly affecting quality of life (Andrew, 2014). However, it is noted that even with the various options and combinations of drugs currently available, analgesic efficacy is still relatively low and there are several adverse effects, commonly requiring a multidisciplinary intervention and a combination of pharmacological and non-pharmacological interventions (Ballantyne, 2018).

The aim of this study was to assess the impact of pharmacological and non-pharmacological interventions on the quality of life of patients with chronic neuropathic pain.

\section{Methodology}

A systematized virtual search was carried out on May 14, 2020 using the PubMed® database. A first search targeted all articles published between January 1, 2010 and May 14, 2020 using the terms "Neuropathic pain", "treatment", "human" and "systematic review" using the filters "Systematic Reviews" and "Published in the last 10 years". A total of 454 articles were found. All articles were analyzed by two independent reviewers and tabulated in a spreadsheet using Microsoft Excel software®.

At first, all articles were analyzed by their titles and abstracts, and all those that did not contain the term Quality of Life in at least their title or abstract were previously excluded. After this first selection, the remaining articles were submitted to the following criteria to be included in this review: [1] the article studies humans as a target population; [2] the article refers to neuropathic pain; [3] the article refers to 'quality of life' as a studied result; [4] the article refers to any type of intervention as treatment; [5] the article is a systematic review. Exclusion criteria were: [1] It is not a systematic review; [2] Articles that do not distinguish neuropathic pain from chronic pain of other etiologies; [3] Articles that do not assess 'quality of life' as a measurable outcome using validated tools; [4] the article does not refer to any type of intervention as treatment; [5] full text not available in at least English, Portuguese or Spanish; [6] inaccessible full text; [7] the article did not assess the quality of evidence and risk of bias of the studies.

The search using the PubMed ${ }^{\circledR}$ database identified 454 articles, of which 413 were excluded in a first screening. Only 41 articles had the full text analyzed and, after applying the eligibility criteria for these remaining articles, only 15 could be elected for inclusion according to the established criteria. All 15 selected articles are systematic reviews and of these, 7 are also meta-analyses (46.6\%). All selected reviews measured the risk of bias and the quality of studies, most of which used some tool to assess the risk of bias and analyze the quality of studies, the most commonly used being the Cochrane 'Risk of bias' tool (60\%) to analyze the risk of bias and the GRADE scale (46.6\%) to analyze the quality of the studies. Other tools less used were AMSTAR Checklist (6.66\%) and ROBINS-I for nonrandomized studies (6.66\%) for risk of bias and Stricta Checklist (6.66\%) and Health Technology16 Assessment-Disease Management instrument $(6,66 \%)$ for study quality - some articles used more than one tool. Only 1 article $(6.66 \%)$ did not use any defined tool despite having independently assessed the risk of bias and the quality of the studies analyzed.

This review was structured according to the Preferred Reporting Items for Systematic Reviews and Meta-Analysis (PRISMA) guidelines. The study selection process is illustrated in the PRISMA flowchart (Figure 1). 
Figure 1. Flowchart PRISMA.

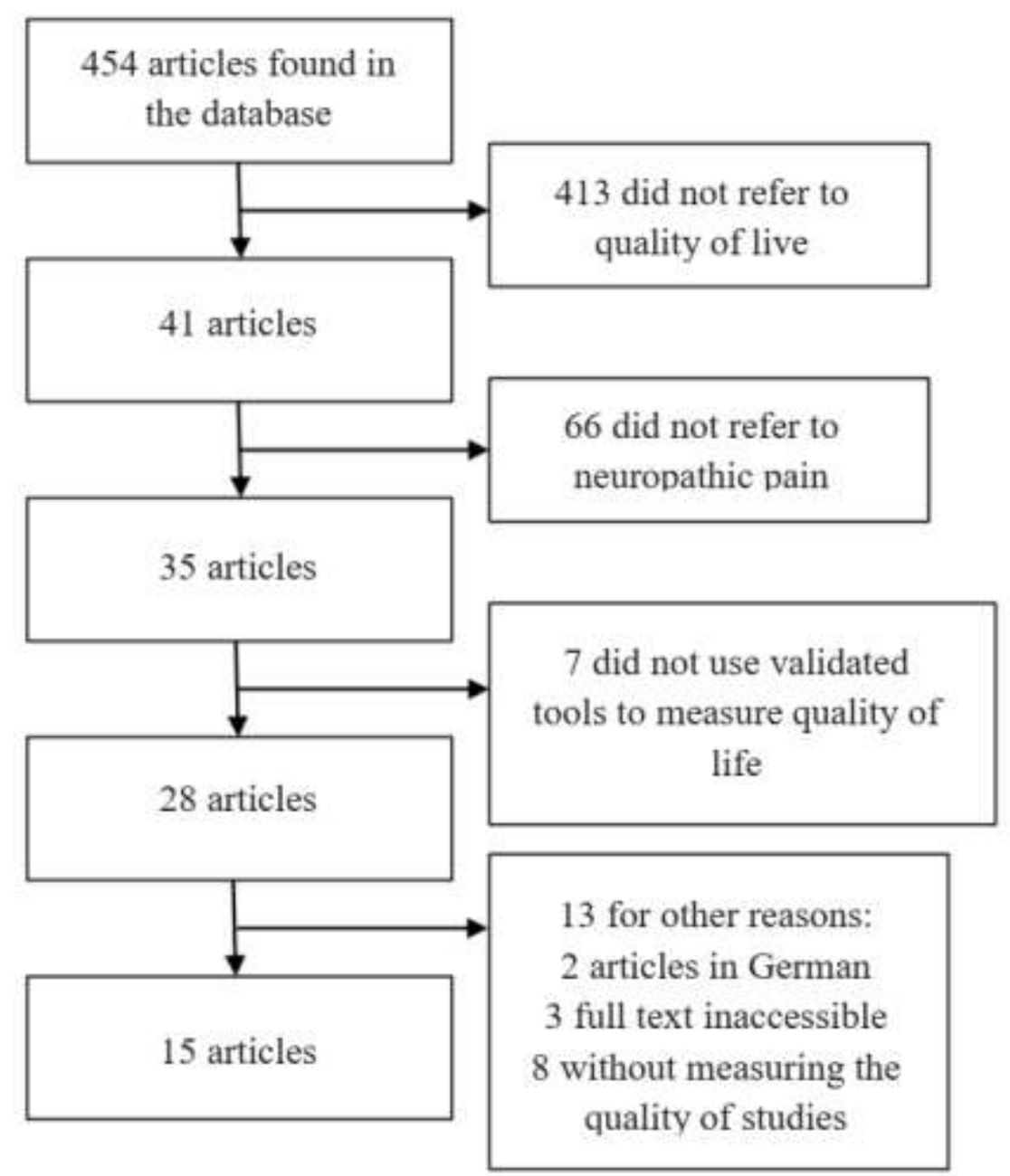

Source: Authors.

In all, 21 tools for measuring quality of life were used. The number of times the tool was used in at least one study of a review was quantified. The most frequently used tools were the 36-Item Short Form Health Survey (80\%) and the EuroQol-5 dimensions (26.6\%), followed by the 12-Item Short-Form Health Survey (13.3\%) and the Life Satisfaction Questionnaire (13.3\%). While 6 articles looked for the variable quality of life as a primary outcome (40\%), 9 articles assessed pain relief as a primary outcome and quality of life as a secondary outcome (60\%). The tools used to measure quality of life and its respective prevalence in reviews was described in Table 1. 
Research, Society and Development, v. 10, n. 14, e416101422250, 2021

(CC BY 4.0) | ISSN 2525-3409 | DOI: http://dx.doi.org/10.33448/rsd-v10i14.22250

Table 1. Tools for measuring quality of life.

\begin{tabular}{lc}
\hline \multicolumn{1}{c}{ Tools } & $\boldsymbol{N}(\%)$ \\
\hline Medical Outcomes Study-36 Item Short From Hearth Survey (SF-36) & $12(80 \%)$ \\
\hline Medical Outcomes Study-12 Item Short From Hearth Survey (SF-12) & $2(13,3 \%)$ \\
\hline EuroQol-5 Dimension (EQ-5D) & $4(26,6 \%)$ \\
\hline Beck Depression Inventory Score (BDI) & $3(20 \%)$ \\
\hline Sickness Impact Profile (SIP) & $1(6,66 \%)$ \\
\hline Brief Pain Inventory (BPI) & $1(6,66 \%)$ \\
\hline Brief Pain Inventory modified for people with disabilities & $1(6,66 \%)$ \\
\hline Oral Health Impact Profile (HIP-49) & $1(6,66 \%)$ \\
\hline Oral Health Impact Profile Reduced Version (OHIP-14) & $1(6,66 \%)$ \\
\hline Spitzer Quality of Life Index 15-0 (Spitzer QLI) & $1(6,66 \%)$ \\
\hline Pain Disability Index 0-80 (PDI) & $1(6,66 \%)$ \\
\hline Subjective Quality of Life Scale (SQOL) & $1(6,66 \%)$ \\
\hline Perceived Quality of Life Scale (PQOL) & $1(6,66 \%)$ \\
\hline $\begin{array}{l}\text { European Organization for Research and Treatment of Cancer Core Quality } \\
\text { of Life Questionnaire (QLQ-C30) }\end{array}$ & $1(6,66 \%)$ \\
\hline $\begin{array}{l}\text { Quality of life questiionnaire to assess chemotherapy-induced peripheral } \\
\text { neuropathy (QLQ-CIPN20) }\end{array}$ & $1(6,66 \%)$ \\
\hline NeuroQoL & $1(6,66 \%)$ \\
\hline Life Satisfaction Questionnaire (Lisat-9) & $2(13,3 \%)$ \\
\hline Likert Scale & $1(6,66 \%)$ \\
\hline
\end{tabular}

* Some reviews mention more than one tool.

Source: Authors.

\section{Results}

In a total of 15 articles: 5 addressed only pharmacological interventions (27.7\%) and 8 addressed nonpharmacological interventions (55.5\%). Of these 15 articles, 2 addressed both types of intervention (13.3\%). Other studies focused on a specific type of etiology and not just the type of intervention. All interventions along with their respective control group, as well as the quality of life measurement tools for each article are listed in Table 2. 
Table 2. Data from articles on neuropathic pain and its tools used in this study.

\begin{tabular}{|c|c|c|c|c|}
\hline Article & QoL Assessment & $\begin{array}{c}\text { Bias Risk Assessment/ } \\
\text { Quality of Studies }\end{array}$ & Intervention & Group Control \\
\hline $\begin{array}{l}\text { Asnani et al., } \\
2019 .\end{array}$ & SF-36 & $\begin{array}{c}\text { Cochrane' Risk of bias' tool/ } \\
\text { GRADE }\end{array}$ & Pregabalin & Placebo. \\
\hline Boldt et al., 2014 & $\begin{array}{l}\text { BDI; SQOL; } \\
\text { PQOL; Lisat-9; } \\
\text { SF-12; BPI } \\
\text { modified }\end{array}$ & $\begin{array}{c}\text { Cochrane' Risk of bias' tool/ } \\
\text { GRADE }\end{array}$ & $\begin{array}{c}\text { CBT, physical exercises for } \\
\text { people with disabilities*, } \\
\text { stimulation by cranial } \\
\text { electrotherapy } 100 \mathrm{mÂ}(\mathrm{CES}) .\end{array}$ & $\begin{array}{l}\text { Waiting list, one-hour } \\
\text { educational video, CES } \\
\text { placebo. }\end{array}$ \\
\hline $\begin{array}{l}\text { Eccleston, Hearn } \\
\text { \& Williams, } \\
2015 .\end{array}$ & $\begin{array}{l}\text { BPI; SF-36 ou } \\
\quad \text { SF-12. }\end{array}$ & Cochrane' Risk of bias' tool/- & CBT & Waiting list. \\
\hline $\begin{array}{l}\text { Gibson, Wand \& } \\
\text { O'connell, } 2017 .\end{array}$ & SF-36 & $\begin{array}{c}\text { Cochrane' Risk of bias' tool/ } \\
\text { GRADE }\end{array}$ & TENS & $\begin{array}{c}\text { Placebo, conventional } \\
\text { treatments or TENs with } \\
\text { conventional treatment vs } \\
\text { TENs. } \\
\end{array}$ \\
\hline $\begin{array}{l}\text { Gibson et al., } \\
2019 .\end{array}$ & SF-36; EQ-5D & AMSTAR checklist/ GRADE & TENS & $\begin{array}{c}\text { TENS placebo, TENS vs any } \\
\text { other active therapy. }\end{array}$ \\
\hline $\begin{array}{l}\text { Li, Giustini \& } \\
\text { Seely, } 2019 .\end{array}$ & $\begin{array}{l}\text { QLQ-C30; QLQ- } \\
\text { CIPN20 }\end{array}$ & $\begin{array}{c}\text { Cochrane' Risk of bias' tool/ } \\
\text { Stricta checklist }\end{array}$ & $\begin{array}{l}\text { Acupuncture and } \\
\text { electroacupuncture. }\end{array}$ & $\begin{array}{c}\text { Low-frequency acupuncture } \\
\text { delayed } 8 \text { weeks post- } \\
\text { intervention and placebo. }\end{array}$ \\
\hline $\begin{array}{l}\text { McMillan et al., } \\
2016 .\end{array}$ & $\begin{array}{c}\text { SF-36; OHIP-14; } \\
\text { OHIP-49; BDI }\end{array}$ & $\begin{array}{c}\text { Cochrane' Risk of bias' tool/ } \\
\text { GRADE }\end{array}$ & $\begin{array}{c}\text { LLLT and dietary supplements } \\
* * \text {. }\end{array}$ & Placebo. \\
\hline $\begin{array}{l}\text { Meng et al., } \\
2017 .\end{array}$ & SF-36; EQ-5D & $\begin{array}{c}\text { Cochrane' Risk of bias' tool/ } \\
\text { GRADE }\end{array}$ & $\begin{array}{c}\text { Dronabinol; Nabilone; } \\
\text { Nabiximols } \\
\end{array}$ & $\begin{array}{c}\text { Placebo and conventional } \\
\text { treatments. }\end{array}$ \\
\hline $\begin{array}{l}\text { Mücke et al., } \\
2017 .\end{array}$ & $\begin{array}{l}\text { Spitzer QLI; EQ- } \\
\text { 5D; SF-36; PDI } \\
0-80 ; \text { SIP }\end{array}$ & $\begin{array}{c}\text { Cochrane' Risk of bias' tool/ } \\
\text { GRADE }\end{array}$ & $\begin{array}{l}\text { Oromucous spray of THC/CBD; } \\
\text { Nabilone; Dronabinol; Inhaled } \\
\text { Cannabis. }\end{array}$ & Placebo. \\
\hline $\begin{array}{l}\text { Rasouli et al., } \\
2014 .\end{array}$ & $\begin{array}{l}\text { SF-36, SF-12, } \\
\text { Likert scale }\end{array}$ & $\begin{array}{c}\text { Cochrane' Risk of bias' tool/ } \\
\text { GRADE }\end{array}$ & $\begin{array}{l}\text { MID (minimally invasive } \\
\text { discectomy) vs MD/OD. }\end{array}$ & $\begin{array}{l}\text { Comparison between the two } \\
\text { techniques. }\end{array}$ \\
\hline $\begin{array}{l}\text { Riesmsma et al., } \\
2011 .\end{array}$ & SF-36; EQ-5D & Cochrane' Risk of bias' tool/ - & $\begin{array}{c}\text { Tapentadol, Oxicodone, } \\
\text { Fentanyl, Transdermal, } \\
\text { Oxymorphone. }\end{array}$ & $\begin{array}{l}\text { Tapentadol vs other opioids, } \\
\text { tapentadol vs placebo. }\end{array}$ \\
\hline $\begin{array}{l}\text { van Laake- } \\
\text { Geelen et al., } \\
2019 .\end{array}$ & $\begin{array}{c}\text { SF-36; } \\
\text { NeuroQoL }\end{array}$ & $\begin{array}{c}\text { Cochrane' Risk of bias' } \\
\text { tool/ROBINS-I }\end{array}$ & $\begin{array}{l}\text { Aerobic exercises, Tai Chi, CBT } \\
\text { and mindfulness meditation. }\end{array}$ & No active therapy. \\
\hline $\begin{array}{l}\text { Waldfogel et al., } \\
2017 .\end{array}$ & SF-36; EQ-5D & - & Pregabalin & Placebo. \\
\hline $\begin{array}{l}\text { Wetering et al., } \\
2010 .\end{array}$ & SF-36, BDI, BPI & HTA-DM & $\begin{array}{c}\text { Cognitive Behavioral Therapy } \\
\text { (CBT) }\end{array}$ & $\begin{array}{l}\text { Supportive psychotherapy or } \\
\text { other active treatment. }\end{array}$ \\
\hline $\begin{array}{l}\text { Wiffen } \text { et al., } \\
2017\end{array}$ & SF-36 & -/GRADE & Gabapentin & Placebo. \\
\hline
\end{tabular}

*Physical training (and bimonthly educational session): distance exercise program, consisting of shoulder strengthening, stretching, transfer techniques, lifting and propulsions, associated with stimulation by cranial electrotherapy of 100 microamps.

** Dietary supplement: Hypericum perforatum and lycopene extracts.

GRADE: Grading of Recommendations, Assesment, Development and Evaluations; HTA-DM: Health Technology Assessment-Disease Management instrument; LLLT: Low Level Laser Therapy (laserterapia de baixa intensidade); CBT: Cognitive Behavioral Therapy; TENS: Transcutaneous Electrical Nerve Stimulation (Neuroestimulação Elétrica Transcutânea); BPI: Brief Pain Index; PDI: Pain Disability Infex; Spitzer QLI: Spitzer Quality of Life Index. Source: Authors.

All systematic reviews included analyzed the quality of evidence of their selected studies. The 8 articles that did not assess the quality of evidence from the included studies were excluded (Girach et al., 2019; Harrisson et al., 2017; Parravano et al., 2019; Doth, Hansson, Jensen, \& Taylor, 2010; Andrew et al., 2010; Andrew et al., 2010; Noble et al., 2010; Zakrzewska, 2011; Anju et al., 2019). The wide etiological variety of neuropathic pain found in the summary of results, 
together with the omission of etiology in studies of at least 5 reviews (Meng et al., 2017; Mücke et al., 2018; Wetering, 2010; Riemsma et al., 2011; Gibson et al., 2019) made it difficult to analyze this point of view.

\section{Discussion}

In the reviews searched, we found analyzes of numerous drugs used in the management of neuropathic pain. Among them, two reviews specifically addressed the class of cannabinoids and cannabis-based drugs (Meng et al., 2017, Mücke et al., 2018).

Meng and collaborators (2017) analyzed 8 studies, generally classifying them as moderate quality and weak recommendation. Of these, 5 showed improvement in quality of life with the use of selective cannabinoids in relation to the control group and 3 did not observe any difference. One of the studies showed an improvement in the Bodily Pain and Mental Health domains of the SF-36 in the group using Dronabinol $2.5 \mathrm{mg}$ to $10 \mathrm{mg}$ daily for 3 weeks on placebo. Another study showed an improvement when using Nabilone 1 to $4 \mathrm{mg}$ daily for 5 weeks compared to the placebo group according to the EQ-5D and the use of Nabilone $2 \mathrm{mg}$ daily for 6 weeks compared to the use of Dihydrocodeine $240 \mathrm{mg} / \mathrm{day}$ showed an improvement in Physical Function domain of the SF-36, although Dihydrocodeine has been shown to be superior in the Bodily Pain domain (Meng et al., 2017).

The THC/CBD Oromucous Spray was addressed in 5 studies carried out by Meng et al. (2017), in two studies they used 8 daily doses for 4 weeks and while one showed improvement in the intervention group according to the BPI and EQ-5D questionnaires, the other showed no difference in relation to the placebo group according to the SF-36 questionnaire; another study that used 4 daily doses of the spray for 12 weeks did not report any difference in the improvement in the quality of life of the groups according to the SF-36 and EQ-5D; and when using 8 daily doses of the spray for 2 weeks, it reported improved quality of life in the intervention group according to the GHQ-12 questionnaire (Meng et al., 2017).

In a systematic review and meta-analysis, Mücke et al. (2018) compared studies of any cannabis drug with placebo, analyzing nine studies with 1284 participants. In one of the studies it was concluded that cannabis drugs were not superior to placebo in improving health-related quality of life (SMD 0.02, 95\% CI -0.10 to 0.13 ; P value $0.79 ; \mathrm{I} 2=0 \%$ demonstrating a quality of low evidence). In a comparison of studies with enriched enrollment randomized withdrawal design, two studies with 68 participants could be qualitatively analyzed where the estimated difference between the THC/CBD spray and placebo was 1.94 (P value 0.18 ). The HrQoL score was $0.74 \pm 0.03$ for Nabilone and $0.60 \pm 0.8$ in the placebo group ( $\mathrm{P}$ value $<0.05$ ) in another study with very low quality of evidence. Analyzing studies that compared cannabinoids to other drugs, the same intervention analyzed by Meng et al. (2017) was found, however there seems to be no difference between Nabilone and Dihydrocodeine with a treatment difference of 8.9 (P value 0.48, moderate quality of evidence) (Mücke et al., 2018).

The great heterogeneity of studies in relation to the difference in dosage and quality of life measurement tools, difficulty in analyzing the effectiveness of cannabinoids in improving the quality of life of patients. Although some studies show an improvement in the quality of life with Nabilone and THC / CBD Oromucosal Spray, the low quality of evidence and contrasting results make it impossible to say that they are really effective. Dronabinol, despite showing positive results, was analyzed in only one study, lacking further studies for comparative analysis (Mücke et al., 2018).

A review by Wiffen and collaborators (2017) found a poor quality investigation showing the use of Gabapentin $3600 \mathrm{mg}$ for 8 weeks as beneficial compared to placebo according to the SF-36 in 55\% of patients for all causes of pain neuropathic. However, of the 229 study participants, only 9 had their quality of life measured through the questionnaire. The scarcity of studies and the small number of patients who underwent the study of quality of life, not only made it impossible to draw any grounded conclusions about quality of life, but also highlighted quality of life as an aspect still neglected in many scientific studies. (Wiffen et al., 2017). 
Waldfogel and collaborators (2017) found 10 studies of low quality of evidence involving pregabalin and quality of life, of which 4 show significant improvement, while 6 show no improvement compared to the placebo group according to the SF-36 (Waldfogel et al., 2017). In the review carried out by Asnani et al. (2019) it was shown that the quality of life of patients using pregabalin did not improve compared to the placebo group according to the SF-36, however in three months of followup, a small improvement could be noted in 7 of 8 SF-36 domains post-intervention in the intervention group compared to the placebo group, all via the quality of evidence is very low (Asnani et al., 2019).

The small number of studies, the low quality of evidence, and the limited use of quality of life measurement tools precluded any conclusions about the benefits of pregabalin on the quality of life of patients with neuropathic pain.

Riemsma and collaborators (2011) conducted a review looking for the impact of treatment with stage 3 opioids according to the WHO on the quality of life of patients with chronic pain, however, they did not find studies involving patients diagnosed with chronic pain of neuropathic etiology. Thus, it was not possible to analyze the effectiveness of any opioid in terms of quality of life (Riemsma et al., 2011).

Chronic neuropathic pain can still be managed using non-pharmacological techniques. Rasouli et al. (2014) comparatively studied through a systematic review the impacts of minimally invasive discectomy (MID) and microdiscectomy/open discectomy (MD/OD) in patients with neuropathic radicular low back pain. As a result, we found only studies with low quality of evidence suggesting that an MID was subtly associated with a lower quality of life (less than 5 points on a 100 scale) in some quality of life measures, such as some physical subclasses of SF-36. Patients discovering MD / OD felt subtly better in some physical aspects of their quality of life, however the difference is negligible. Despite the apparent superiority of MD / OD over MID with regard to the quality of life of patients, the data should be provided with caution, as they are of low quality of evidence and used only one measurement method for analysis (Rasouli et al., 2014).

The use of transcutaneous electrical neurostimulation (TENS) in neuropathic pain was analyzed in two reviewed reviews, although they are insufficient to report the benefit of the effect of TENS on health-related quality of life due to the very low quality of selection and precariousness of the studies (Gibson, Wand \& O'connell, 2017; Gibson et al., 2019).

The use of low-intensity laser therapy (LLLT) was studied by McMillan and collaborators (2016) showing short-term improvement in quality of life in patients with burning mouth syndrome reporting LLLT (McMillan et al., 2016).

Four reviews addressed cognitive behavioral therapy (CBT), three articles looked at psychological therapies in general (Eccleston, Hearn \& Williams, 2015; Van Laake-Geelen et al., 2019; Boldt et al., 2014), one article sought CBT as a specific intervention (Van de Wetering et al., 2010).

Van de Wetering and collaborators (2010) only two studies, out of thirteen included, that reported quality of life. A study with good quality of evidence, evaluated by the HTA-DA tool, was a randomized clinical trial with an 18-month followup. The study authors reported positive effects on quality of life and early discharge in the intervention group compared to the common psychological therapy group according to the SF-36 questionnaire, but only in female patients. The second study distinguished differences in quality of life between the intervention group and the control groups according to the BDI. They received attenuating cognitive behavioral therapy greater reduction in depressive symptoms, stress levels, and functionality interference than they received standard supportive psychotherapy (Van de Wetering et al., 2010).

In the evaluation carried out by Eccleston, Hearn \& Williams (2015), a study was found that observed improvements in the quality of life of patients according to the Life Satisfaction Questionnaire (LiSat-9) after CBT, however there was no difference between the intervention group and the control group (Eccleston, Hearn \& Williams, 2015). The same study was included by Boldt and collaborators (2014) who considered it with a high risk of bias and low quality of evidence mainly because of the choice of a control group with a waiting list (Boldt et al., 2014). Van Lake-Geelen and collaborators (2019) 
found a study involving CBT that, however, did not report data on quality of life in their patients (Van Lake-Geelen et al., 2019).

The small number of studies makes it difficult to affirm the real benefits of CBT for the quality of life of patients with neuropathic pain. The presence of a good quality study, in line with the beneficial results of some lower quality studies, may evidence the beneficial effect on CBT. However, studies of adequate quality need to be carried out, especially using adequate quality of life measurement tools and the choice of the control group.

A review by Li, Giustini and Seely (2016) analyzed two studies regarding the use of acupuncture and quality of life in chemotherapy-induced neuropathic pain. Both studies showed low quality of evidence and low risk of bias and while one showed an improvement in quality of life comparing electroacupuncture with placebo, according to the QLQ-C30 and QLQCIPN20 questionnaires, another that studied traditional acupuncture compared with the same therapy, delayed and to a lesser extent, it showed no difference in results between the control and intervention groups (Li, Giustini \& Seely 2016). The low quantity and quality of studies found made any comparative analysis impossible.

In the review by Van Laake-Geelen and collaborators (2019) found 2 studies of moderate quality of application in meditative practices. Mindfulness meditation in patients with painful peripheral diabetic neuropathy compared to any active treatment does not alter the effects related to quality of life according to the NeuroQol scale. Another study involving a mindfulness-based stress-reduction program improves quality of life compared to the group that does not touch the intervention, however, there was no mention of the tool used for such measurement. As only one study results using a validated tool for measuring quality of life, it was not possible to carry out a comparative analysis (Van Laake-Geelen et al., 2019).

A review by Boldt and collaborators (2014) studied the quality of life in patients with neuropathic pain from spinal cord injury. He found two studies involving an exercise program aimed at people with disabilities. The first study involves physical exercise training and educational meetings for patients with paraplegia and quadriplegia. The quality of life of patients was measured using the PQOL questionnaire and the mean difference was 10.8 (95\% CI -4.2 to 25.8; P value 0.16). The second study involved a home exercise training program to optimize movement, consisting of shoulder strengthening and stretching exercises, along with recommendations on how to optimize transfer techniques, lifts, and wheelchair propulsions. The control group used a minimum one-hour educational video intervention. The SQOL scale was used to measure quality of life in the short and medium term and the mean differences were 0.3 (95\% CI - 0.22 to 0.82 ; P value 0.25 ) and 0.5 (CI $95 \%$ 0.03 to 1.03; P value 0.07), respectively. Both studies were classified as having low quality of evidence (Boldt et al., 2014). Van Laake-Geelen and collaborators (2019) included in their review a clinical trial of moderate quality of evidence that positive effects of aerobic exercise with significant improvement in at least 6 domains of the NeuroQol scale in patients with painful diabetic peripheral neuropathy (Van Laake-Geelen et al., 2019).

McMillan and collaborators (2016) conducted a review of a burning mouth syndrome in which the effectiveness of different dietary supplements in improving the quality of life of these patients was analyzed. A study with Lycopene (n: 50, very low quality of evidence) showed no short-term difference in quality of life according to the OHIP-14 score (MD 0.93, 95\% CI -3.14 at 5.00 effect; $\mathrm{P}=0.65$ ). Another study comparing Hypericum perforatum extract with placebo (n: 43 ,: very low quality of evidence), does not use appropriate tools for measuring quality of life (McMillan et al., 2016). No studies involving dietary supplements were performed with long-term follow-up. In addition to the low quality of evidence, there were no other studies with the dietary supplements mentioned, which precluded any comparative analysis of their benefits in relation to the quality of life of patients with neuropathic pain. 


\section{Conclusion}

Only one review (6.6\%) reported having a single good-quality study according to the Health Technology Assessment Tool - Disease Assessment (HTA-DM) assessment tool, despite the fact that the overall quality of their studies was very low. to moderate (Van de Wetering et al., 2010). Most reviews have a variety of low (33\%) or very low (26.6\%) quality studies. Three reviews (20\%) rated their included studies as moderate quality of evidence (Meng et al., 2017; Wiffen et al., 2017; Van LaakeGeelen et al., 2019). One review (6.6\%) classified their studies as 'very low to moderate quality' (Mücke et al., 2018). Only one review (6.6\%) that does not use a GRADE scale rated the quality of evidence of their studies as 'poor' and at high risk of bias (Waldfogel et al., 2017). However, as some reviews (40\%) sought quality of life as a secondary outcome, not all of these studies that have their quality assessed or sought to present quality of life results. Also because these reviews are a secondary result, an exposition and synthesis of data related to quality of life were often neglected or insufficiently specific.

Most presentations present a small number of studies involving quality of life, which made the analysis of the variable difficult. Furthermore, there is little homogeneity and frequency in the use of questionnaires to measure quality of life. It should also be noted that most of the interventions reported refer to alternative or third-line treatments, which necessarily means that most studies involving first and second-line interventions did not address the quality of life variable.

Thus, it is necessary to carry out studies with adequate methodology, having the life variable systematically analyzed using more than one questionnaire or validated score to assess actions in neuropathic pain, in order to confirm the information pointed out by low-quality studies, as the contribution of cognitive behavioral therapy and the use of THC / CBD oromucous spray in the quality of life of patients with chronic neuropathic pain.

\section{References}

Andrew, R., Derry, S., Taylor, R. S., Straube, S. \& Phillips, C. J. (2014). The costs and consequences of adequately managed chronic non-cancer pain and chronic neuropathic pain, Pain Practice, 14 (1), 79-94.

Anju, M., Ummer, S., Maiya, A. G. \& Hande, M. (2019). Low level laser therapy for the patients with painful diabetic peripheral neuropathy-A systematic review. Diabetes \& Metabolic Syndrome: Clinical Research \& Reviews, 13 (4), 2667-2670.

Asnani, M. R., Francis, D. K., Brandow, A. M., Gabbadon, C. E. H. \& Ali, A. (2019). Interventions for treating neuropathic pain in people with sickle cell disease. Cochrane Database of Systematic Reviews, 7 (7), 1-25.

Ballantyne, J. C., Fishman, S. M. \& Rathmell, J. P. (2018). Bonica's management of pain. Lippincott Williams \& Wilkins.

Boldt, I., Eriks-Hoogland, I., Brinkhof, M. W. G., Bie, R., Daniel, J. \& Elm, E. V. (2014). Non-pharmacological interventions for chronic pain in people with spinal cord injury. Cochrane Database of Systematic Reviews, 1 (11), 1-70.

Chen, J. (2011). History of pain theories. Neuroscience bulletin, 27 (5), 343-350.

Collier, R. (2018). A short history of pain management. Canadian Medical Aassociation Joule, 190(1), 26-27.

Doth, A. H., Hansson, P. T., Jensen, M. P. \& Taylor, R. S. (2010). The burden of neuropathic pain: a systematic review and meta-analysis of health utilities. Pain, 149 (2), 338-344.

Eccleston, C., Hearn, L. \& Williams, A. C. C. (2015). Psychologicaltherapies for the management of chronic neuropathic pain in adults. Cochrane Database of Systematic Reviews, 1 (10), 1-30.

Gibson, W., Wand, B. M., Meads, C., Catley, M. J. \& O'connell, N. E. (2019). Transcutaneous electrical nerve stimulation (TENS) for chronic pain- an overview of Cochrane Reviews. Cochrane Database of Systematic Reviews, 2 (2), 1-31.

Gibson, W., Wand, B. M. \& O'Connell, NE. (2017). Transcutaneous electrical nerve stimulation (TENS) for neuropathic pain in adults. Cochrane Database of Systematic Reviews, 9 (9), 1-69.

Girach, A., Julian, T. H., Varrassi, G., Paladini, A., Vadalouka, A. \& Zis, P. (2019). Quality of life in painful peripheral neuropathies: a systematic review. Pain Research and Management, 2019 (1), 1-9.

Hadzic, A., Sadeghi, N., Vandepitte, C., Vandepite, W., Van de Velde, M., Hadzie, A., Van Robays, J., Heylen, R., Herijgers, P., Vloka, C., Zundert, J. V. (2014). 500th birthday of Andreas Vesalius, the founder of modern anatomy:"vivitur ingenio, caetera mortis erunt"("genius lives on, all else is mortal"). Regional Anesthesia \& Pain Medicine, 39 (6), 450-455. 
Harrisson, S. A., Stunes, S., Dunn, K. M., Foster, N. E. \& Konstantinou, K. (2017). Neuropathic pain in low Back-Related leg pain patients: what is the evidence of prevalence, characteristics, and prognosis in primary care? A systematic review of the literature. The Journal of Pain, 18 (11), $1295-1312$.

Jensen, T.S., Baron, R., Haanpää, K. E., Loeser, J. D., Rice, A. S. C \& Treede, R. (2011). A new definition of neuropathic pain. Pain, 152 (10), $2204-2205$.

Li, K., Giustini, D. \& Seely, D. (2019). A systematic review of acupuncture for chemotherapyinduced peripheral neuropathy. Current Oncology, 26 (2), 147154.

McMillan, R., Forssell, H., Buchanan, J. A., Glenny, A. M., Weldon, J. C. \& Zakrzewska, J. M. (2016). Interventions for treating burning mouth syndrome. Cochrane Database of Systematic Reviews, 11 (11), 1-109.

Meng, H., Johnston, B., Englesakis, M., Moulin, D. E. \& Bhatia, A. (2017). Selective cannabinoids for chronic neuropathic pain: a systematic review and meta-analysis. Anesthesia \& Analgesia, 125 (5), 1638-1652.

Meyer-Rosberg, K., Burckhardt, C. S., Huizar, K., Kvarnström, A., Nordfos, L. O. \& Kristofferson, U. (2001). A comparison of the SF-36 and Nottingham Health Profile in patients with chronic neuropathic pain. European Journal of Pain, 5 (4), 391-403.

Miranda, C. C. V., Seda Jr, L. F. \& Pelloso, L. R. C. A. (2016). Nova classificação fisiológica das dores: o atual conceito de dor neuropática. Revista Dor, 17 (1), 2-4.

Moayedi, M. \& Davis, K. D. (2013). Theories of pain: from specificity to gate control. Journal of Neurophysiology, 109 (1), 5-12.

Mücke, M., Philips, T., Radbruch, L., Petzke, F. \& Häuser, W. (2018). Cannabis-based medicines for chronic neuropathic pain in adults. Cochrane Database of Systematic Reviews, 3 (3), 1-91.

Noble, M., Treadwell, J. R., Tregear, S. J., Coates, V. H., Wiffen, P. J., Akafomo, C. \& Choelles, K. M. (2010). Long-term opioid management for chronic noncancer pain. Cochrane database of systematic reviews, 1 (1), 1-64.

Parravano, D. C., Ciampi, D. A., Fonoff, E. T., Monaco, B., Navarro, J., Yeng, L. T., Teixeira, M. J. \& Hamani, C. (2019). Quality of life after motor cortex stimulation: clinical results and systematic review of the literature. Neurosurgery, 84 (2), 451-456.

Perl, E. R. (2007). Ideas about pain, a historical view. Nature Reviews Neuroscience, 8 (1), 71-80.

Raja, S. N., Carr, D. B., Cohen, M., Finnerup, N. B., Flor, H., Gibson, S., Keefe, F. J., Mogil, J. S., Ringkamp, M., Sluka, K. A., Xue-Jun, C., Stevens, B., Sullivan, M. D., Tutelman, P. R., Ushida, T. \& Vader, K. (2020). The revised International Association for the Study of Pain definition of pain: concepts, challenges, and compromises. Pain, 161 (9), 1976-1982.

Rasouli, M. R., Rahimi-Movaghar, V., Shokraned, F., Moradi-Lakeh, M. \& Chu, R. (2014). Minimally invasive discectomy versus microdiscectomy/open discectomy for symptomatic lumbar disc herniation. Cochrane Database of Systematic Reviews, 1 (9), 1-61.

Riemsma, R., Forbes, C., Harker, J., Worthy, G., Misso, K.., Schafer, M.; Kleijnen, J. \& Stürzebecher, S. Systematic review of tapentadol in chronic severe pain. Current medical research and opinion, 27 (10), 1907-1930.

Scholz, J., Finnerup, N. B., Attal, N., Aziz, Q., Baron, R., Bennett, M. I., Benoliel, R., Cohen, M., Cruccu, G., Davis, K. D., Evers, S., First, M., Giamberardino, M. A., Hansson, P., Stein, K., Korwisi, T., Perrot, S., Raja, S. N., Rice, A. S. C., Rowbotham, M. C., Schug, S., Simpson, D. M., Smith, B. H., Svensson, P., Vlaeyen, J. W. S., Wang, S. J., Barke, A., Rief, W., Treede, R.D. (NeuroPSIG). (2019) . The IASP classification of chronic pain for ICD-11: chronic neuropathic pain. Pain, 160 (1), 53-59.

Van de Wetering, E. J., Lemmens, K. M. M., Nieboer, A. P. \& Huijsman, R. Cognitive and behavioral interventions for the management of chronic neuropathic pain in adults-a systematic review. European journal of Pain, 14 (7), 670-681.

Van Laake- Geelen, C. C. M., Smeets, R. J. E. M., Quadflieg, S. P. A. B., Kleijnen, J. \& Verbunt, J. A. (2019). The effect of exercise therapy combined with psychological therapy on physical activity and quality of life in patients with painful diabetic neuropathy: a systematic review. Scandinavian Journal of Pain, $19(3), 433-439$.

Waldfogel, J. M., Nesbit, S. A., Dy, S. M., Sharma, R., Zhang, A., Wilson, L. M., Bennet, W. L., Yeh, H. C., Chelladurai, Y., Feldman, D. \& Robinson, K. A. (2017). Pharmacotherapy for diabetic peripheral neuropathy pain and quality of life: a systematic review. Neurology, 88 (20), $1958-1967$.

Wiffen, P. J., Derry, S., Bell, R. F., Rice, A. S. C. \& Tölle, T. R. (2017). Gabapentin for chronic neuropathic pain in adults. Cochrane Database of Systematic Reviews, 6 (6), 1-113. 